\title{
Experimental Modeling of Biogeosorbents
}

\author{
T. Shchemelinina ${ }^{1}$, O. Kotova ${ }^{2}$, E. Anchugova ${ }^{1}$, D. Shushkov ${ }^{2(\bowtie)}$, \\ G. Ignatyev ${ }^{2}$, and M. Markarova ${ }^{2}$ \\ ${ }^{1}$ Laboratory of Biochemistry and Biotechnology, Institute of Biology, \\ Komi Science Center, Ural Branch of the Russian Academy of Sciences, \\ Syktyvkar, Russia \\ 2 Laboratory of Technology of Mineral Raw, Institute of Geology named after \\ Academician N.P. Yushkin Komi Science Center of the Ural Branch \\ of the Russian Academy of Sciences, Syktyvkar, Russia \\ dashushkov@geo.komisc.ru
}

\begin{abstract}
A new trend in the modeling algorithm oil sorption materials is the adsorptive immobilization of strains of microorganisms on mineral sorbent. The objects of study were clay and zeolite raw and biogeosorbents with oil-oxidizing microorganisms from Biotrin preparation, immobilized on them. During our work we modeled biogeosorbents and estimated their sorption and destructive properties in reference to petroleum hydrocarbons.
\end{abstract}

Keywords: Biogeosorbents - Biotrin - Petroleum hydrocarbons - Sorption • Zeolites · Clays

\section{Introduction}

One of the most promising ways to solve problem of oil pollution is to use biogeosorbents, which are sorbent-carriers with oil-oxidizing microorganisms immobilized on their surface (Shchemelinina et al. 2017). It is possible to use zeolite and clay raw as mineral carriers, which have high ion-exchange and sorption properties (Kotova et al. 2017). The purpose of this work is to study sorption and destructive properties of biogeosorbents based on clay and zeolite raw as mineral carriers for Biotrin biopreparation.

\section{Methods and Approaches}

The objects of study were:

1. Mineral carriers based on analcime-bearing rocks from Koinskaya zeolite area (Shushkov et al. 2006), clinoptilolite-bearing clays and glauconite-bearing rocks from Chim-Loptyugskoe oil shale deposit (Saldin et al. 2013; Simakova 2016), located in Komi Republic (Russia). For comparison, Ionsorb TM quartz-glauconite sand from Bondarskoe deposit of Tambov region was taken as a control. 
2. Strains of microorganisms in the composition of Biotrin biopreparation (Conclusion .. 2017): bacteria Pseudomonas yamanorum VKM B-3033D, isolated from heavily soiled railway bed near the city of Syktyvkar (Patent $2615458 \mathrm{RU}$ ); yeast Rhodotorula glutinis VKM Y-2998D (Patent 2658134 RU); microalgae Chlorella vulgaris Beijer. f. globosa V. Andr. A1123. Microorganisms (cell titer 109) were cultivated according to standard methods. Immobilization of the biopreparation on mineral carriers was carried out in the ratio of 1 part of the biopreparation to 6 parts of the sorbent. Initial sorbents (without Biotrin) and biogeosorbents were added to oilcontaminated water, aerated for 4 days, and total petroleum hydrocarbons (TPH) content in water samples, filtered initial sorbents and biogeosorbents was measured (Method ... 1998).

\section{Results and Discussion}

Norms for maximum permissible concentration (MPC) of TPH in water of fishery value are $0.05 \mathrm{mg} / \mathrm{dm}^{3}$ (Order ... 2016). The TPH content in the control water sample is 2.4 times higher than MPC (Table 1).

Experiments showed that samples of the initial analcime-bearing rocks (551, $56403,1 / 83$ ) presented adsorption activity in relation to oil products. As a result of the introduction of these samples into oil-polluted water, the content of pollutant in water decreases 2.5-3 times in 4 days, to the MPC. When biogeosorbents are applied to contaminated water $(551-\mathrm{B}, 56403-\mathrm{B}, 1 / 83-\mathrm{B})$, the efficiency of water purification decreases and does not reach MPC standards, which indicates decreasing sorption properties after immobilization of microorganisms on the mineral carriers. This is probably due to decreasing surface area of the mineral carriers covered by microorganisms. During the study of initial samples and Biotrin treated samples for destructive properties we revealed that the efficiency of oxidation of oil products in samples 551-B, 56403-B, 1/83-B increases in 4.4, 3.5 and 1.14 times, respectively.

The sorption properties of clinoptilolite-bearing clays are most attractive in sample 541-31. However, taking into account a highly destructive activity of microorganisms in 538-35-B biogeosorbent, it is preferred for remediation of oil contaminated water.

Samples of initial glauconite-bearing rocks have high sorption properties (539-40, 531-56, 315-10, TG). The TPH content in the experimental water is reduced by $3.4-5$ times in 4 days relative to a control sample. Biodegradation of hydrocarbons in samples of Biotrin immobilized glauconite-bearing rocks (539-40-B, 531-56-B, 315-10-B, TG-B) ranges from 62 to $76 \%$. 
Table 1. Change in the concentration of oil products in water in the presence of initial mineral carriers and biogeosorbents

\begin{tabular}{|c|c|c|c|}
\hline Initial samples & TPH content* & Biotrin treated samples & TPH content* \\
\hline \multicolumn{4}{|c|}{ Analcime-bearing rocks } \\
\hline 551 & $\frac{0.04 \pm 0.014}{250 \pm 60}$ & $551-\mathrm{B}$ & $\frac{0.11 \pm 0.04}{57 \pm 23}$ \\
\hline 56403 & $\frac{0.046 \pm 0.016}{130 \pm 50}$ & 56403-B & $\frac{0.061 \pm 0.021}{37 \pm 15}$ \\
\hline $1 / 83$ & $\frac{0.048 \pm 0.017}{250 \pm 60}$ & $1 / 83-\mathrm{B}$ & $\frac{0.071 \pm 0.025}{220 \pm 90}$ \\
\hline 58603 & $\frac{0.071 \pm 0.025}{250 \pm 60}$ & 58603-B & $\frac{0.064 \pm 0.022}{90 \pm 40}$ \\
\hline \multicolumn{4}{|c|}{ Clinoptilolite-bearing clays } \\
\hline $538-35$ & $\frac{0.085 \pm 0.030}{50 \pm 20}$ & $538-35-\mathrm{B}$ & $\frac{0.037 \pm 0.013}{40 \pm 16}$ \\
\hline $541-31$ & $\frac{0.035 \pm 0.012}{250 \pm 60}$ & $541-31-B$ & $\frac{0.058 \pm 0.021}{100 \pm 40}$ \\
\hline \multicolumn{4}{|c|}{ Glauconite-bearing rocks } \\
\hline $539-40$ & $\frac{0.024 \pm 0.009}{58 \pm 23}$ & 539-40-B & $\frac{0.072 \pm 0.025}{20 \pm 8}$ \\
\hline $531-56$ & $\frac{0.027 \pm 0.009}{63 \pm 25}$ & 531-56-B & $\frac{* *}{15} \pm 6$ \\
\hline $315-10$ & $\frac{0.09 \pm 0.03}{11 \pm 4}$ & $315-10-\mathrm{B}$ & $\frac{0.021 \pm 0.007}{17 \pm 7}$ \\
\hline TG & $\frac{0.035 \pm 0.012}{90 \pm 40}$ & TG-B & $\frac{0.045 \pm 0.016}{34 \pm 14}$ \\
\hline
\end{tabular}

Oil-contaminated water (control) $0.12 \pm 0.041$

Note: $*$ - in the numerator, TPH content in the experimental water, $\mathrm{mg} / \mathrm{dm}^{3}$, in the denominator - TPH content in the initial sorbents and biogeosorbents after the experiment, $\mathrm{mg} / \mathrm{g}$. $* *$ no data

\section{Conclusions}

Our experiments resulted in modeling of biogeosorbents based on clay and zeolite raw and oil-oxidizing microorganisms from Biotrin biopreparation immobilized on them. We determined that samples of initial sorbents showed a high adsorption activity with respect to oil products. TPH content in water was reduced by $2.5-5$ times, up to or substantially below MPC. We revealed that microorganism cells could reduce sorption properties of mineral carriers, at the same time providing oil destruction. Biodestruction of oil products with biogeosorbents for 4 days was $12-77 \%$.

Acknowledgments. The authors express their gratitude to the Center for Collective Use "Geonauka", ecoanalytical laboratory of the Institute of Biology of the Komi Science Center UB RAS for their assistance in analytical work. The work was carried out with the partial financial support of UB RAS Programs (project 18-5-5-44), UMNIK project (12412GU/2017), of the State 
task "Development of biocatalytic systems based on enzymes, microorganisms and plant cells, their immobilized forms and associations for the processing of plant raw, production of biologically active substances, biofuels, remediation of contaminated soils and wastewater treatment" No. AAAA-A17-117121270025-1, "Scientific basis for effective subsoil use, development and exploration of mineral resource base, development and implementation of innovating technologies and economic zoning of the Timan-Nothern Ural region" No. AAAA-A17117121270037-4.

\section{References}

Certificate on the toxicological and hygienic assessment of "BIOTRIN" consortium of strains of oil-oxidizing microorganisms. State federal enterprise for science Research center for toxicology and hygienic regulation of biopreparations at Federal medico-biological agency, Serpukhov, 28 September 2017 (in Russian)

(1998) Method for performing measurements of the mass fraction of petroleum products in soil samples on a Fluorat-02 analyzer. Institute of Biology of Komi Science Center of the Ural Branch of the Russian Academy of Sciences, 16.1.21-98, Moscow, 15 p (in Russian)

Patent of the Russian Federation No. 2615458

Patent of the Russian Federation No. 2658134

Order of the Ministry of Agriculture of the Russian Federation of December 13, 2016 No. 552. On approval of water quality standards for water bodies of fishery importance, including standards for maximum permissible concentrations of harmful substances in the waters of water bodies of fish-economic importance (in Russian)

Saldin VA, Burtsev IN, Mashin DO, Shebolkin DN, Inkina NS (2013) Marking horizons in the Upper Jurassic deposits of the Yarengsky shale region (north-east of the Russian plate), no 11, pp 26-29. Vestnik of the Institute of Geology of the Komi Science Center UB RAS (in Russian)

Simakova YuS (2016) Features of globular layered silicates of the Chim-Loptyugsky oil shale deposit, № 9-10, pp 52-57. Vestnik of the Institute of Geology of the Komi Science Center UB RAS (in Russian)

Shushkov DA, Kotova OB, Kapitanov VM, Ignatiev AN (2006) Analcime rocks of Timan as a promising type of minerals. Syktyvkar, $40 \mathrm{p}$ (Scientific recommendations to the national economy/Komi Science Center UB RAS, issue 123) (in Russian)

Shchemelinina TN, Kotova OB, Harja M, Anchugova EM, Pelovski I, Kretesku I (2017) New trends in the mechanisms of increasing the productivity of materials on a mineral basis, no 6 , pp 40-42. Vestnik of the Institute of Geology of the Komi Science Center UB RAS (in Russian)

Kotova OB, Harja M, Cretescu I, Noli F, Pelovski Y, Shushkov DA (2017) Zeolites in technologies of pollution prevention and remediation of aquatic systems, no 5, pp 49-53. Vestnik of the Institute of Geology of the Komi Science Center UB RAS 
Open Access This chapter is licensed under the terms of the Creative Commons Attribution 4.0 International License (http://creativecommons.org/licenses/by/4.0/), which permits use, sharing, adaptation, distribution and reproduction in any medium or format, as long as you give appropriate credit to the original author(s) and the source, provide a link to the Creative Commons license and indicate if changes were made.

The images or other third party material in this chapter are included in the chapter's Creative Commons license, unless indicated otherwise in a credit line to the material. If material is not included in the chapter's Creative Commons license and your intended use is not permitted by statutory regulation or exceeds the permitted use, you will need to obtain permission directly from the copyright holder.

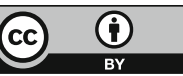

